\title{
Turnustjeneste og spesialistutdanning - en nervøs romanse
}

\begin{abstract}
Sammendrag
Med Det medisinske fakultet i Oslo som initiativtaker og pådriver ble turnustjeneste innført i to trinn sykehustjeneste fra sommeren 1954 , distriktstjeneste fra sommeren 1955. Med obligatorisk praksistjeneste etter avlagt medisinsk embetseksamen skulle de medisinske kandidatene forberedes på sitt yrkesliv før de ble autorisert som leger. Turnustjeneste i distrikt lot seg innføre fordi Legeforeningen lempet på spesialistreglenes krav om ett år med allmennpraksis for alle leger i spesialisering. Det var et omstridt «offer». Innad i profesjonsforeningen ble spørsmålet om forholdet mellom turnustjeneste og spesialistutdanning ikke løst før i 1965.
\end{abstract}

Artikkelen bygger på utdrag fra Haave $P$. I medisinens sentrum. Den norske legeforening og spesialistregimet gjennom hundre år. Oslo: Unipub, under utgivelse 2011.

\section{Per Haave}

per.haave@medisin.uio.no Seksjon for medisinsk antropologi og medisinsk historie

Avdeling for samfunnsmedisin Institutt for helse og samfunn Det medisinske fakultet Universitetet i Oslo

I eksil under den annen verdenskrig begynte Karl Evang (1902-81) - Norges helsedirektør fra 1938 til 1972 - å legge planer for velferdsstatens helsevesen. Med rasjonelle tiltak basert på medisinsk kunnskap skulle «det norske folks helse og arbeidskraft» gjenreises (1-3) (fig 1). Det medisinske studium ble tiltenkt en viktig rolle. Som Hans Jacob Ustvedt (1903-82) hjelpelærer ved Det medisinske fakultet i Oslo og overlege ved Ullevål sykehus sa i Det norske medicinske Selskab i 1946: «Vi kan være med på å heve produksjonskapasiteten og levestandarden, og først og fremst øke menneskenes trivsel om vi skaper en medisinsk undervisning som gjør lægene rustet til å fylle den store oppgave de har i fremtidens samfunnsliv» (4) (fig 2). Da måtte imidlertid studentene forberedes bedre på sitt yrkesaktive liv som praktiserende leger enn det som inntil da hadde vært mulig. Det var, fremholdt kirurgiprofessor Johan Holst (1892-1953), en stor svakhet at «de unge læger som făr sin licentia ikke behersker de praktiske ferdigheter som er så viktige for den praktiserende læge $\mathrm{i}$ hans daglige virke» (5).

\section{Ny studieplan \\ ved Det medisinske fakultet i Oslo}

Etter frigjøringen ble undervisningen ved universitetet påbegynt høsten 1945. Det medisinske fakultet fikk flest eksamenskandidater, over 200 både i 1946 og 1947. Antallet skyldtes at køen av studenter fra før 1940 - da medisinstudiet ble lukket (6) skulle avvikles hurtigst mulig. Med provisoriske tiltak presset fakultetet flere kandidater gjennom enn det normal kapasitet skulle tilsi (7). I 1946 ble det bestemt at de provisoriske tiltakene skulle avløses av en ny studieordning. En bredt sammensatt komité ledet av Johan Holst leverte en innstilling i desember 1948. To hovedtiltak ble foreslått: Studietiden, normert til 7-7 1/2 år, burde forkortes med ett år og undervisningen burde styrkes - to motstridende tiltak som bare kunne forenes ved å gjøre studiet mer skolemessig, med detaljert timeplan og flere lærere, og ved å avlaste studiet ved å innføre obligatorisk turnustjeneste på halvannet år etter embetseksamen. Det ble forutsatt at ingen kandidater skulle få anledning til «å utøve selvstendig legevirksomhet» før turnustjenesten var utført (8).

Det medisinske fakultet fremmet - etter å ha behandlet studieplankomiteens innstilling i 19 møter - sitt forslag om en ny, permanent studieordning i februar 1950. Den ble vedtatt av Stortinget samme året, og iverksatt i 1951. Det store målet var «oppdragelse til lægegjerning» $(8,9)$. Obligatorisk turnustjeneste lot imidlertid vente på seg. Etter planen skulle den bestå av halvannet års tjeneste - et halvt år i henholdsvis kirurgisk og indremedisinsk sykehusavdeling, og et halvt år hos «praktiserende, offentlig læge», det vil si distriktslege som også drev privat praksis.

Den påtenkte turnusordningen var nokså lik den generelle tjenesten som alle kommende spesialister, unntatt tannlegekirurger og spesialister i laboratoriefag, måtte utføre i henhold til Legeforeningens spesialistregler av 1918. Den generelle delen i spesialistutdanningen besto til sammen av ett års kirurgisk og medisinsk tjeneste i sykehus, foruten ett år med egen allmennpraksis, eventuelt tjeneste hos distriktslege. Hensikten med dette kravet var å ivareta en generell medisinsk orientering hos legespesialistene. Det gjaldt å unngå «den store fare» at spesialister så «for ensidig på sin spesialitet», slik Niels Aars Nicolaysen (1885-1958) - mangeårig medlem av spesialitetskomiteen i kirurgi - sa det på Legeforeningens landsmøte i 1932 (10).

Sommeren 1948 hadde sentralstyret, Legeforeningens politiske ledelse, gitt sin støtte til forslaget om en turnustjeneste på halvannet år. Sentralstyret var også blitt spurt om spesialistreglenes krav om ett år med allmennpraksis kunne sløyfes dersom et halvt år hos distriktslege gikk gjennom. Etter alt å dømme ble dette halve året tenkt som en tilstrekkelig innføring i allmennpraksis for kommende spesialister, og det ble ansett som urimelig å kreve ytterligere generell praksisopplæring. Fire av sentralstyrets fem medlemmer var villige til å redusere det ene året med et halvt år, det femte medlemmet ville ikke godta noen avkorting (11). Det tegnet til strid.

\section{Forslag om turnustjeneste - med krav til Legeforeningen}

I 1949 ble spørsmålet om turnustjeneste drøftet på Legeforeningens landsmøte det åpne legemøtet - og det etterfølgende

\section{Hovedbudskap}

- Turnustjenesten ble innført i 1954/55 for å bygge bro mellom teoretisk og praktisk medisin

- Innføringen av turnustjeneste i distrikt ble gjort avhengig av at Legeforeningen reduserte kravet om allmenn praksis i spesialistutdanningen

- Legeforeningen opplevde et press fra Det medisinske fakultet i Oslo, og ga motvillig etter

- I 1965 stilte Legeforeningen utført turnustjeneste som vilkår for spesialistgodkjenning, og avviklet siste rest av spesialistreglenes krav om allmennpraksis 


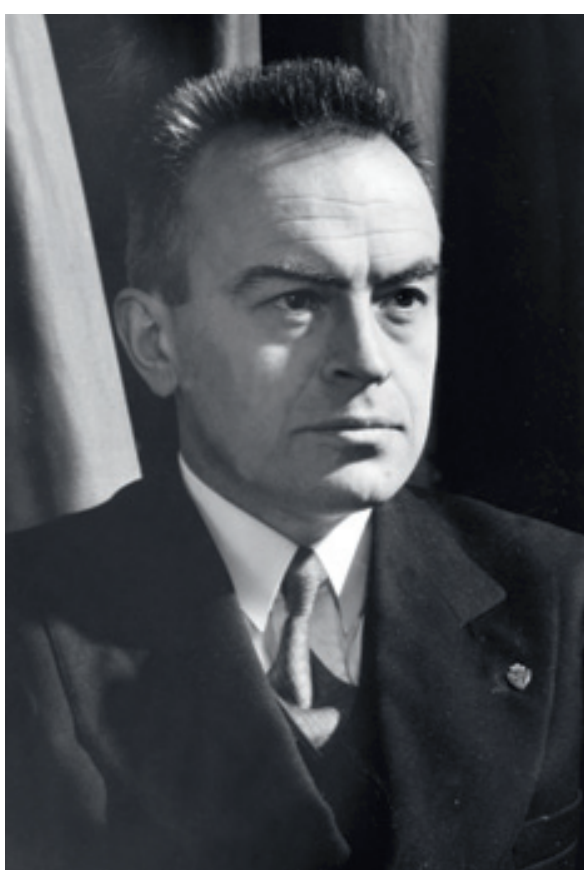

Figur 1 Medisinaldirektør Karl Evang (1902-81) fotografert i London 5.1. 1944. På denne tiden la han planer for etterkrigstidens helsetjeneste. Foto NTB-arkiv/SCANPIX

landsstyremøtet med valgte representanter som fra samme året erstattet landsmøtet som foreningens lovgivende forsamling (12). I saksfremlegget - skrevet av sentralstyrets daværende leder, president Axel Strøm (1901-85), som også var professor i hygiene 1940-51 - het det at turnuskandidatenes sykehustjeneste burde godkjennes som generell sykehustjeneste for leger som ønsket å spesialisere seg. Strøm ville imidlertid ikke anbefale noen endring i spesialistreglene. Ordningen var ennå ikke vedtatt, og det var dermed usikkert hvilken endelig form den ville få $(13,14)$.

I 1950 hadde styret i Yngre lægers forening støttet forslaget om at en turnustjeneste på halvannet år skulle erstatte spesialistreglenes krav om generell tjeneste. Det ga forslaget legitimitet blant yngre leger, den mest berørte gruppen. Forutsetningen var imidlertid at Legeforeningen godtok dette - fakultetet kunne ikke egenhendig endre foreningens spesialistregler (8). Odd Bjercke (1909-2005) - Legeforeningens generalsekretær fra 1949 til og med mars 1976 - fikk i sakens anledning besøk av «en deputasjon fra fakultetet med professor Johan Holst i spissen» som gjorde det klart at det ikke ville bli noe av turnustjeneste hos distriktslege dersom foreningen satte seg imot (15).

Da saken kom opp på Legeforeningens landsmøte i 1953, var det ingen som protesterte mot at turnustjeneste i sykehus skulle erstatte kravet i de generelle spesialistreglene om tjeneste i henholdsvis kirurgisk og indremedisinsk avdeling. Derimot sto det strid om hvorvidt det skulle lempes på reglenes krav om allmennpraksis. Sentralstyret, med Trygve Iversen (1902-89) stadsfysikus i Oslo 1951-72 - som

Axel Strøms etterfølger i presidentstolen 1952-53, hadde i saksfremlegget foreslått at kravet kunne senkes fra ett til et halvt år for leger med utført turnustjeneste hos distriktslege (16).

I Det medisinske fakultet var det fremfor

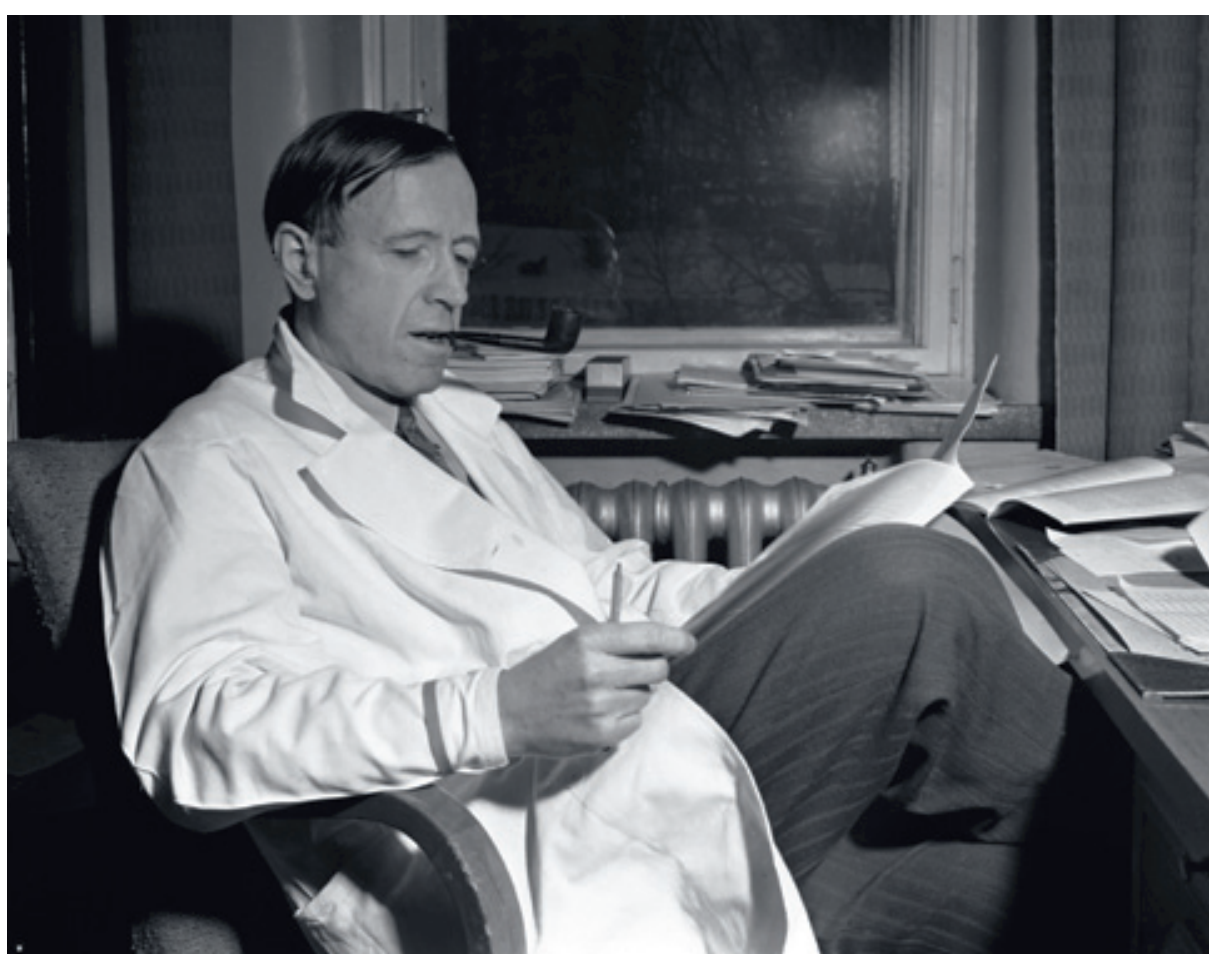

Figur 2 Hans Jacob Ustvedt (1903-82) fotografert 1.2. 1954 i hvit frakk på sitt kontor, røyker pipe og leser dokumenter. Han var overlege ved 9. avdeling, Ullevål sykehus 1946-59 og professor i indremedisin 1951-62. Foto NTB/Scanpix alt Axel Strøm - fra 1951 professor i sosialmedisin - som hadde ivret for tjeneste i distrikt. Det hadde vært enighet i fakultetet om en sykehustjeneste. Derimot hadde forslaget om et halvt års tjeneste hos praktiserende, offentlig lege kun latt seg redde med et knapt flertall. Kritiske fakultetsmedlemmer fant tjeneste i distrikt overflødig, og mente dessuten at turnustjenesten da ville bli for lang. «Personlig er jeg helt uenig i dette,» sa Strøm på landsmøtet i 1953. Hovedhensikten med medisinstudiet var å utdanne praktikere, og da var det «nærmest vanvittig å slippe ut fra Universitetet folk som ikke har gjort noen slik tjeneste som vi skulle søke å kvalifisere dem til». Men hvis ikke Legeforeningen godtok turnustjeneste i distrikt som tilstrekkelig generell tjeneste i spesialistutdanningen, var Strøm sikker på at forslaget ville falle. I så fall ville turnustjenesten bare komme til å bestå av sykehustjeneste. Han innrømmet at betingelsen var tvilsom, og han var innforstått med at den ergret flere medlemmer. Han ba imidlertid landsmøtedeltakerne innstendig om å støtte sentralstyret - det var «meget viktig at alle læger, uansett om de skal bli privatpraktiserende læger, eller spesialister eller skal inn på institusjon, har hatt en slik «overvåket» tjeneste $i$ et halvt år» (16). Etter alt å dømme anså Strøm det som umulig å få politisk og kollegial - aksept for et forslag som innebar at kommende spesialister måtte tjenestegjøre som allmennpraktikere både i forlengelsen av medisinstudiet og som en innledning til spesialiseringen.

\section{Et «gentlemen's agreement»}

Johan Haffner (1906-89), overlege ved kvinne- og fødeavdelingen ved Tønsberg sentralsykehus og sentralstyremedlem fra 1948, fortalte på landsmøtet i 1953 at et flertall i Legeforeningens sentralstyre anså et halvt år med allmennpraksis i spesialistutdanningen som snaut, men forsto at turnustjeneste i distrikt var avhengig av foreningens standpunkt. Om sentralstyret hadde kunnet handle fritt, ville det fastholdt kravet om ettårig allmennpraksis for leger som ville bli spesialister, for i størst mulig grad å forebygge ensidighet i spesialistenes virke. Sentralstyret vurderte det likevel slik at det i denne omgang var viktigere at alle leger fikk «et halvt års praksis under betryggende forhold, enn å sikre oss at de vordende spesialister har dekning for praksis». En annen møtedeltaker - landsstyremedlem og privatpraktiserende øyespesialist Ludvig Wirsching (1898-1974) i Kristiansand - kunne ikke forstå at fakultet, departement og Storting ville «droppe en så viktig bestemmelse» som turnus i distrikt, hvis Legeforeningen satte seg mot - «det er dog en liten del som fortsetter og blir spesialister» (16).

Helsedirektøren, som hadde sittet i studieplankomiteen, fortalte at det halve 
året hos distriktslege var et kompromiss. Et komitéflertall hadde opprinnelig ment at turnustjeneste kun skulle bestå av sykehustjeneste, og derfor ikke godtatt Legeforeningens opprinnelige forslag om tjeneste hos privatpraktiserende allmennlege. Disse medlemmene hadde heller ikke godtatt Helsedirektoratets forslag om innføring i sosialmedisin og offentlige legeforretninger. Derfor hadde forening og direktorat i fellesskap fremmet et kompromiss som komiteen godtok. «Vi», sa Karl Evang, «firte på kravet om det administrative og det sosialmedisinske, Lægeforeningen firte på kravet om bare praksis, og så fant vi frem til et halvt års tjeneste hos praktiserende offentlig læge» (16). Evang ba Legeforeningen på det sterkeste om å holde fast ved «dette «gentlemens agreement»»».

\section{Legeforeningen bøyer av}

Landsstyret skulle ta stilling dagen etter landsmøtet. Ludvig Wirsching fastholdt kravet om ett års allmennpraksis i spesialistutdanningen. Karl Evang skulle dessuten ha sagt til ham at Axel Strøms uttalelse på landsmøtet var «noe krass», og at myndighetene trolig ikke ville droppe distriktstjenesten selv om Legeforeningen satte seg mot. Strøm, som også var landsstyremedlem, fremholdt imidlertid at fakultetet måtte behandle saken på nytt dersom landsstyret forkastet forslaget. Da var Strøm sikker på at et flertall i fakultetet ville fjerne kravet om tjeneste hos distriktslege. Hva helsedirektøren skulle ha sagt i en «privatsamtale» var derfor ikke relevant. Dette var en «universitetssak», slo professoren myndig fast (17).

Axel Strøm - Legeforeningens tidligere president 1948-51 - gjorde seg upopulær. «Hvis det går slik at professor Strøm får skremt oss til å gjøre dette som han foreslår,» burde det gå tydelig fram at «hele» landsstyret egentlig ønsket å holde fast ved ett år med allmennpraksis for kommende spesialister, sa Guttorm Gulowsen (1902-86), leder i Vest-Agder Lægeforening. En annen lege lurte på om ikke landsstyrets medlemmer kunne la være å stemme - saken var blitt fremmet på en måte som gjorde det umulig å stemme «fritt». Legeforeningens lover er ikke klare på dette punkt, svarte presidenten, men presiserte at det alltid hadde vært «forutsatt» at alle fremmøtte landsstyremedlemmer stemte over sakene som ble behandlet (17).

Alternative forslag ble fremmet, men forkastet. Ved endelig votering ble sentralstyrets forslag vedtatt, men med en tilføyelse av overlege Anton Johnson (1893-1967) ved øyeavdelingen, Bodø sykehus: Turnus i distrikt skulle kun utføres hos distriktslege som sentralstyret hadde godkjent for oppgaven. På den måten skulle Legeforeningen øve kontroll med offentlige leger med ansvar også for den generelle utdanningen av kommende spesialister (17).

\section{Turnustjenesten innføres}

Turnustjenesten var planlagt som en forlengelse av medisinstudiet, men Kirke- og undervisningsdepartementet mente at praksisopplæring var departementet uvedkommende. Derfor fremmet Sosialdepartementet en kongelig resolusjon om innføring av turnustjeneste (18). Turnustjenesten ble vedtatt 23. april 1954 og innført i to trinn - med sykehustjeneste fra 1. juli 1954 og med distriktstjeneste fra 1. juli 1955. Etter intensjonen ble normert studietid ved Det medisinske fakultet forkortet fra $7-71 / 2$ til 6-6 $1 / 2$ år. Det administrative ansvaret for turnustjenesten ble lagt til Helsedirektoratet, mens utvalget som hadde forberedt det hele, fortsatte som rådgivende organ for direktoratet, og som kontaktorgan for interesserte parter. Foruten å være representert i det rådgivende organet, ble det overlatt til Legeforeningen å regulere forholdet mellom turnuskandidater og distriktsleger på kollegial basis. På grunnlag av en overenskomst mellom Offentlige lægers landsforening og Yngre lægers forening ble det lagd en normalkontrakt for avtaler mellom distriktslegene og kandidatene som skulle ivareta begges økonomiske interesser. Ifølge kontrakten skulle kandidatene være næringsdrivende, med en garantert minsteinntekt, i sitt halve år hos distriktslegen. Distriktslegen skulle stå for utbetalingen, og få halvparten av beløpet refundert fra staten. Behovet for slike avtaler meldte seg, fordi det ikke fantes stillinger i primærlegetjenesten som turnuskandidatene kunne bekle (19-21). Turnuskomiteen som skulle overvåke ordningen, ble etablert i 1955 med Axel Strøm som leder, og med representanter fra fakultetene i Oslo og Bergen, Legeforeningen, Helsedirektoratet og studentene.

I 1955 uttalte generalsekretær Odd

\section{GANG}
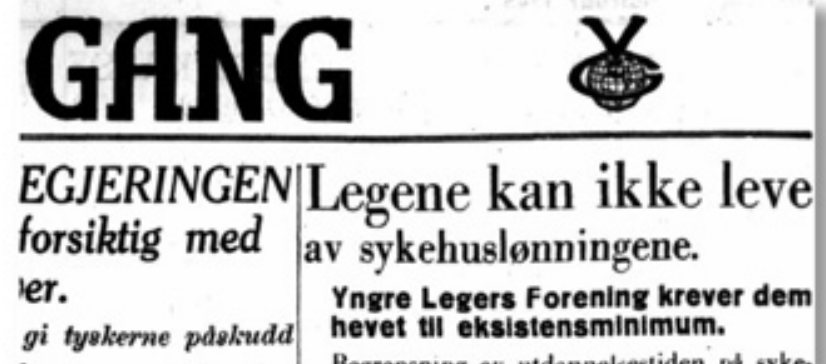

dodsdommen ooer Klinge

Begrensaing av utdanoelsestiden ph syke-

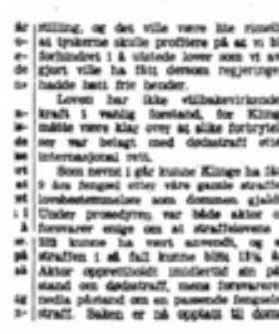

husene enskelig. Mar.

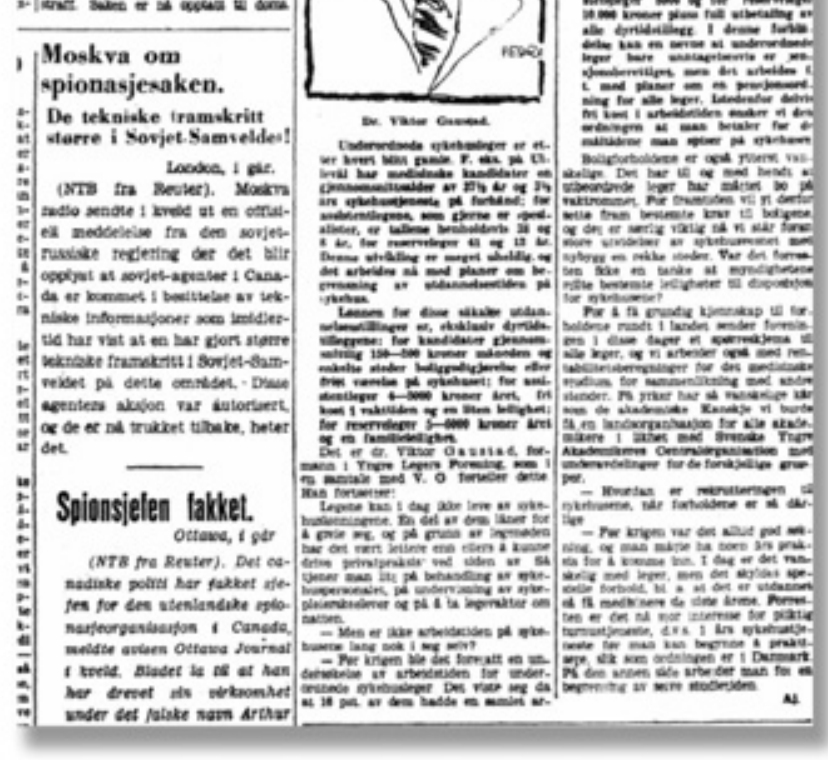

«Forresten er det nå stor interesse for pliktig turnustjeneste, d.v.s. 1 års sykehustjeneste før man kan begynne å praktisere, slik som ordningen er i Danmark. På den annen side arbeider man for en begrens ning av selve studietiden», het det i et intervju med YLF-leder Viktor Gaustad (1907-2003) i Verdens Gang 21.2. 1946 
Bjercke at ett års allmennpraksis fortsatt ble ansett som et nødvendig krav til spesialistenes generelle utdanning. Ledelsen hadde kun gått med på å innlemme et halvt års turnus i distrikt i spesialistutdanningen, fordi visse medlemmer ved Det medisinske fakultet i Oslo hadde lagt et press på foreningen. Bjercke mente imidlertid at sentralstyret fortsatt måtte kunne vurdere spesialistsøkernes praktiske tjeneste, og at dispensasjon fra kravet om ettårig allmennpraksis kun burde gis dersom vedkommende distriktslege hadde innhentet sentralstyrets samtykke til å ha leger i turnus. Dispensasjon måtte i så fall søkes før tjenestestart (22). Noen bestemmelse om turnustjenesten ble imidlertid ikke inntatt i spesialistreglene før i 1965.

\section{«En omgåelse og i realiteten en underkjennelse av Lægeforeningens krav»}

I de nye spesialistreglene - de såkalte Bodø-reglene - ble det fastslått at spesialistutdanningen skulle bygge på utført turnustjeneste og autorisasjon som lege. Dette var blitt foreslått av Seip-utvalget - etter lederen, visepresident Martin Seip (1921-2001), som tidligere hadde representert medisinstudentene i studieplankomiteen av 1946. Derimot skulle leger uten turnustjeneste som hovedregel fortsatt avkreves en generell tjeneste som omfattet ett år med allmennpraksis og ett år med sykehustjeneste (23).

Seip-utvalget hadde foreslått en særnorsk - og i manges øyne en besværlig - sammenfiltring av turnustjeneste og spesialistutdanning. Noe tilsvarende fantes ikke i Norden for øvrig, og var heller ikke påtenkt $i$ en nordisk avtale om felles spesialistregler fra 1964. Men ifølge Seip-utvalget kunne ikke Legeforeningen se bort fra den allerede politisk vedtatte turnustjenesten.

Hvorfor voldte sammenfiltringen besvær? Styret i Alment praktiserende lægers forening satte ord på mange legers oppfatning: Legene hadde vesentlig «møtt spesialisert sykehusmedisin» i sin studietid, et halvt års turnus i distrikt ville derfor ikke gi kommende spesialister tilstrekkelig allmennpraktisk erfaring. Forslaget var ikke bare en «omgåelse», men «i realiteten en underkjennelse» av Legeforeningens krav om ett år med allmennpraksis, hevdet yrkesforeningen, og ga to grunner for at kommende spesialister burde ha mer generell tjeneste enn et halvt år hos distriktslege: En lege kunne ikke «arbeide trygt i sin spesialitet» uten erfaring fra «generell, udifferensiert medisin», og heller ikke yte det beste uten «personlig erfaring fra dette å behandle pasienten $\mathrm{i}$ hans egentlig miljø»». Mer allmennpraktisk erfaring ville fjerne «usikkerhetsfølelsen» hos nye leger, og dessuten skape «større enhet $i$ lægestanden». Nå sto Legeforeningen i fare for å gjøre allmennpraktisk tjeneste «unødvendig, ja, nærmest bortkastet ved en spesialutdannelse». Å slå inn på denne veien ville kunne

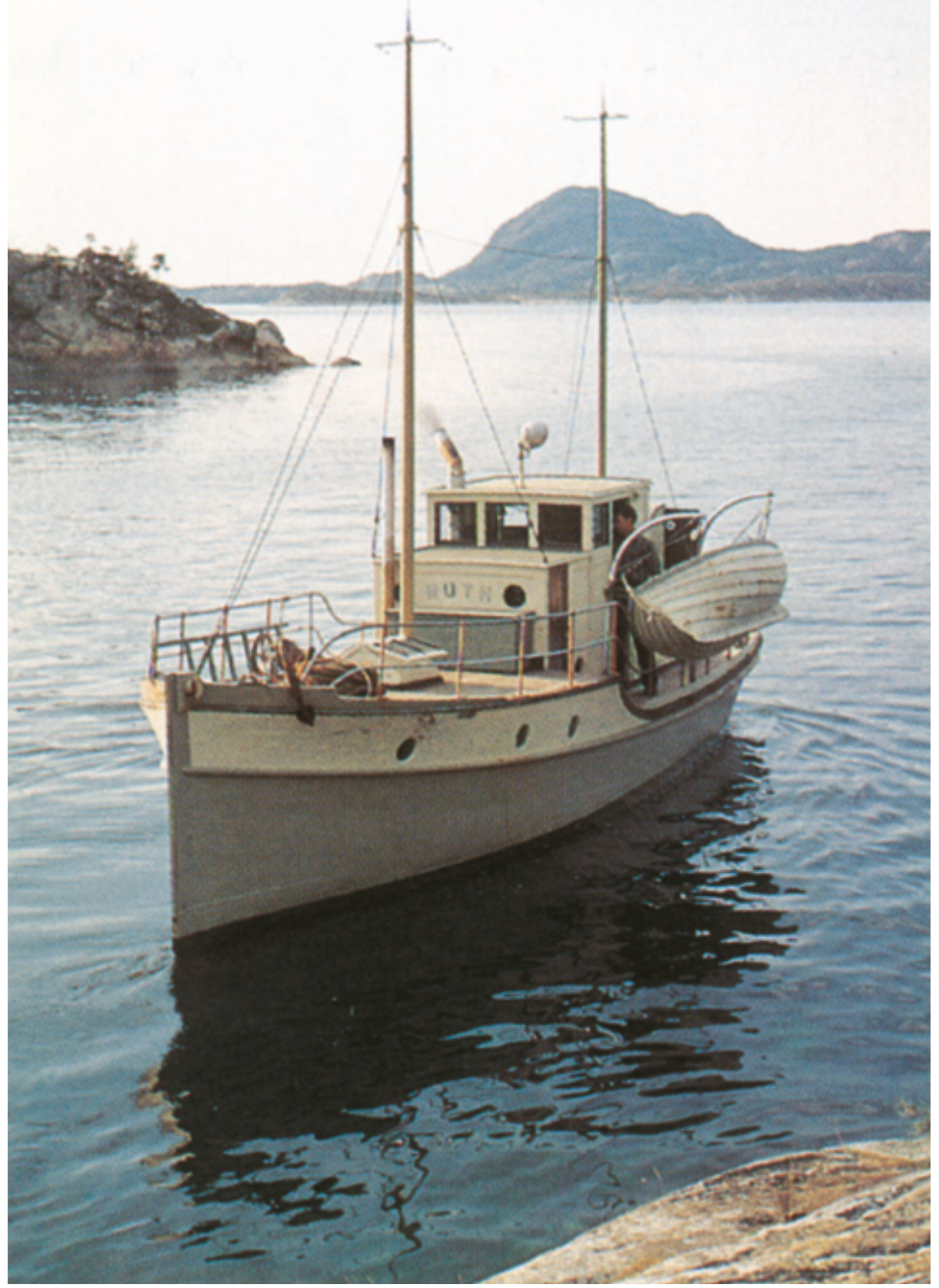

Doktorbåten «Ruth» i Hemne legedistrikt i Sør-Trøndelag var bygd i 1909 og fortsatt i bruk i 1960-årene. Foto Øivind Larsen 1963

få «vidtgående følger for hele vårt helsesystems videre utvikling», advarte yrkesforeningen (24).

\section{Et omstridt amnesti}

På Legeforeningens landsmøte i Bodø i 1965 handlet nesten hele diskusjonen om nye spesialistregler om allmennpraktisk tjeneste. Det skyldtes fremfor alt at sentralstyret i tillegg hadde foreslått at spesialistsøkere med embetseksamen fra før turnustjeneste ble innført i 1954/55, ikke skulle avkreves tjeneste $i$ allmennpraksis.

Sentralstyret siktet til rundt 70 leger som hadde «slått rot i sin gjerning», og som i all hovedsak utførte «spesialistarbeid» i overordnede stillinger i sykehus, men uten å være godkjente spesialister. Blant dem var det også enkelte professorer og andre universitetslærere. Flere av disse legene lærte dessuten opp nye spesialister (25). Mange av dem hadde søkt om spesialistgodkjenning, men fått sine søknader avslått fordi de manglet ett år med allmennpraksis. Dermed var «en rekke av våre fremste folk ikke [...] godkjente spesialister», kommenterte Gerhard Larsen (1907-87) - Legeforeningens president fra 1962 til og med 1965 - på landsmøtet i 1965. Den restriktive praksisen hadde dessuten ført til at spesialistsøkere kom «trekkende med alle mulige selsomme former for privat praksis» (26). 
Seip-utvalget hadde foreslått at de mest fremragende blant disse legene burde innvilges dispensasjon fra kravet om allmennpraksis, men det hadde verken sentralstyret eller generalsekretæren villet godta. Derfor hadde sentralstyret falt ned på det foreliggende forslaget. Det var ikke vellykket, men nødvendig, fremholdt Larsen - som hadde måttet overtale et nølende sentralstyre: «Det er praktisk nå å skjære igjennom dette og få ryddet opp i et villnis som er der og i den misnøye som mer eller mindre berettiget gjør seg gjeldende.» Et amnesti til alle leger uten allmennpraksis, ville riktignok gi en «engangsinflasjon» med spesialistgodkjenning, men Larsen kunne vanskelig se hvordan sentralstyret ellers kunne gjøre rent bord (26).

Mange landsmøtedeltakere mislikte sentralstyrets forslag. En av dem var Kaare Schanke (1906-90), Legeforeningens tidligere president (1958-61). I kritiske vendinger beskrev han en økt tendens, særlig i Det medisinske fakultet i Oslo, til å favorisere basalfagene på bekostning av praktisk medisin. Han mente også å vite at studentene nå var mer opptatt av teori enn av praksis, noe han antok skyldtes utvelgelseskriteriene til et lukket medisinstudium. Fra 1948 fikk kun de flinkeste med artium fra reallinjen eller naturfaglinjen adgang til studiet. Schanke vedgikk at basalfagene hadde vært forsømt, men om pendelen ikke skulle svinge for langt den andre veien, måtte Legeforeningen sørge for at allmennpraksis ikke tapte anseelse blant legene. Da måtte kravet om tjeneste i allmennpraksis fortsatt innta en primær plass i spesialistreglene. Mot dette syndet både Seip-utvalget og sentralstyret, mente Schanke (26).

Flere deltakere sluttet seg til den tidligere presidentens vurderinger. Landsstyremedlem Frithjof Christie (1919-95), privatpraktiker og leder i Alment praktiserende lægers forening fra 1969, var opprørt over at sentralstyret ga «mine til dispensasjoner og avvikelse fra de gamle krav». Det bidro til å gi allmennpraksis et «mindreverdig preg», og noe som var overflødig for «høyverdige spesialister». Generalsekretæren delte kritikken, men bare i prinsippet. Norge hadde nylig tiltrådt avtalen om felles arbeidsmarked for leger i Norden, det hadde han hørt på radioen. Odd Bjercke fryktet derfor «en særdeles bråket situasjon». Nå ville en norsk lege med svensk autorisasjon, men ingen turnustjeneste og allmennpraksis «formodentlig» måtte godtas «på like fot med leger utdannet her hjemme». Derimot måtte «en høyt kvalifisert norsk lege» uten allmenn praksis «måtte holdes tilbake.» I tillegg var det ikke krav om allmennpraktisk tjeneste i den nordiske avtalen fra 1964 om felles spesialistregler. Et absolutt krav om slik tjeneste kunne derfor umulig fastholdes i Norge, mente Bjercke. Det var grunnen til at sentralstyret ville avskaffe kravet om allmenn- praksis for leger med medisinsk embetseksamen fra før 1954. Dette var, sa Bjercke, «den norske måte å avfinne seg med den nordiske situasjon på» (26).

Diskusjonen på landsstyremøtet dagen etter brakte ingen nye synspunkter. En første avstemning ga et flertall for at spesialistreglene heretter skulle bygge på full autorisasjon som lege, og at leger uten turnustjeneste skulle ha vært i allmennpraksis $i$ ett år. Ti av 69 landsstyremedlemmer stemte imot. Dermed falt spesialistreglenes krav om ett års tjeneste i allmennpraksis. Sentralstyrets forslag om amnesti for leger med embetseksamen fra før 1954 ble vedtatt med 43 stemmer for og 26 imot (27).

\section{Brobygging i går - og i morgen}

Med turnusordningen ble allmennpraksis og sykehustjeneste i indremedisinsk og kirurgisk sykehusavdeling et vilkår for legeautorisasjon. Det skulle bygges bro mellom teoretisk og praktisk medisin - den medisinske utdanningen skulle bli mer praksisnær. Det var hovedhensikten med turnustjenesten. Men fordi Legeforeningen allerede hadde innført en nærmest tilsvarende tjeneste for kommende spesialister, stilte Det medisinske fakultet i Oslo krav om at spesialistreglene ble tilpasset turnustjenesten. Hvis ikke ble det antatt at en ordning med turnus i distrikt ikke ville la seg innføre.

Legeforeningen ga motvillig etter for et opplevd press. I 1953 gikk foreningen med på å lempe på spesialistreglenes krav om ett års allmennpraksis som var blitt vedtatt i 1918 for å forebygge trangsyn og ensidighet i spesialistgjerningen. I 1965 ble siste rest av kravet fjernet $i$ de generelle spesialistreglene. I stedet ble turnustjeneste et vilkår for spesialistgodkjenning.

Det er i dag usikkert hva som vil skje med turnustjenesten, og hva som eventuelt vil erstatte den. Det er imidlertid signalisert både fra helsemyndighetenes og Legeforeningens side at legeautorisasjon bør gis etter avlagt medisinsk embetseksamen og før en obligatorisk tjeneste. Mens turnustjenesten opprinnelig skulle forberede nokså teoretisk skolerte medisinere på en praktisk legegjerning, vil turnustjenesten bli avløst av en ordning som skal markere starten på legenes videre kvalifiseringsløp. For leger flest vil det bety spesialisering. I så fall vil en slik ordning i prinsipp innebære en gjenreisning av Legeforeningens krav om en forberedende spesialistutdanning.

\section{Per Haave (f. 1958)}

er cand.philol. i historie, er statsstipendiat og gjesteforsker ved Seksjon for medisinsk antropologi og medisinsk historie, Universitetet i Oslo.

Ingen oppgitte interessekonflikter.
Litteratur

1. Nordby T. Karl Evang. En biografi. Oslo: Aschehoug, 1989: 125-8, 171-92.

2. Seip A-L. Veiene til velferdsstaten. Norsk sosialpolitikk 1920-75. Oslo: Gyldendal, 1994: 313-6.

3 Schiøtz A. Folkets helse - landets styrke 1850-2003. Det offentlige helsevesen i Norge 1603-2003. Bd. 2. Oslo: Universitetsforlaget, 2003 309- 15 .

4. Ustvedt HJ. Den medisinske undervisning. Tidsskr Nor Lægeforen 1946; 66: 706-10.

5. Holst J. Det medisinske studium. Tidsskr Nor Lægeforen 1946; 66: 697-703.

6. Haave P. Fra fritt til lukket studium. Myndighet og kyndighet i konflikt (1923-1940). I: Benum E. Myhre JE, Skeie J, red. Kunnskapens betingelser Oslo: Vidarforlaget, 2009: 238-61.

7. Collett JP. Historien om Universitetet i Oslo. Oslo: Universitetsforlaget, 1999: 174.

8. Innstilling til ny permanent ordning av det medisinske studium. Avgitt av Det medisinske fakulte ved Universitetet i Oslo 13. februar 1950. Vedlegg til St.prp. nr. 1. Tillegg nr. 19. Oslo: Kirke- og undervisningsdepartementet, 1950

9. Larsen $\emptyset$. Legestudent i hovedstaden - medisin på stadig nye måter. Universitetet i Oslo og innføringen av studieplanen «Oslo96». Oslo: Gyldendal Akademisk, 2002: 44-5.

10. Sak nr. 20. Regler for godkjennelse av specialister og lægers avertering. Forhandlinger på Den norske lægeforenings 24. landsmøte i Bergen 30. juni2. juli 1932. Oslo: Den norske lægeforening, 1932

11. Riksarkivet, Pa 280, De, L0002. Skriv til Undervisningsplankomiteen fra Dnlfs sentralstyre, 22.6.1948.

12. Riksarkivet, $\mathrm{Pa} 280, \mathrm{Aa}, \mathrm{L} 0001$. Stenografisk referat av Dnlfs landsmøte og landsstyremøte i Trondheim, 8.-11.6.1949.

13. Revisjon av spesialistreglene. Tidsskr Nor Lægeforen 1949; 69: 197-200

14. Riksarkivet, Pa 280, De, L0002. Brev til Dnlfs sentralstyre fra A. Strøm, 28.2.1949.

15. Sak nr. 13. Forslag til nye spesialistregler. Tidsskr Nor Lægeforen 1966; nr. 21b-10.

16. Riksarkivet, Pa 280, Aa, L0001. Sak nr. 11. Endring av «Spesialistregler for Den norske lægeforening». Forhandlinger i Den norske lægeforenings 32. landsmøte 20. og 21. august 1953 og Forhandlinger i Den norske lægeforenings landsstyremøte 22. august 1953

17. Riksarkivet, Pa 280, Aa, L0001. Sak nr. 10. Endring av «Spesialistregler for Den norske lægeforening». Forhandlinger i Den norske lægeforenings 32. landsmøte i 20. og 21. august 1953 og Forhand linger i Den norske lægeforenings landsstyremøte 22. august 1953

18. Brinchmann-Hansen $\AA$. 50 år i år - lenge leve tur nustjenesten? Tidsskr Nor Lægeforen 2004; 124 : $2110-2$.

19. Sentralstyrets melding om Den norske lægeforenings virksomhet 1 . juli 1953-1. mai 1955. Tidsskr Nor Lægeforen 1955; 75: 363-90.

20. Sentralstyrets melding om Den norske lægefor enings virksomhet 1. mai 1955-20. august 1957 Tidsskr Nor Lægeforen 1957: 77: 759-77.

21. Skaset M. I gode og onde dager ... De norske legene og staten 1945-2000. Doktoravhandling. Oslo: Det medisinske fakultet, Universitetet i Oslo, 2006: 103.

22. Riksarkivet, Pa 280, De, L0002. Brev til Dnlfs sentralstyre fra sekretariatet ved O. Bjercke og K. Rambech, 20.12.1955.

23. Innstilling av 30. november 1964 fra Utvalget til å foreslå revisjon av spesialistreglene. Tidsskr Nor Lægeforen 1965; 85: 573-82.

24. Riksarkivet, Pa 280, De, L0005. Brev til Dnlf fra Alment praktiserende lægers forening ved $\mathrm{R}$. Mathisen, 11.3.1965.

25. Riksarkivet, Pa 280, De, L0005. Brev til Dnlfs sentralstyre fra O. Bjercke, 2.4.1965

26. Sak nr. 7. Forslag til nye spesialistregler. Tidsskr Nor Lægeforen 1966; nr. 21b-10.

27. Sak nr. 13. Forslag til nye spesialistregler. Tidsskr Nor Lægeforen 1966; nr. 21b-10. 